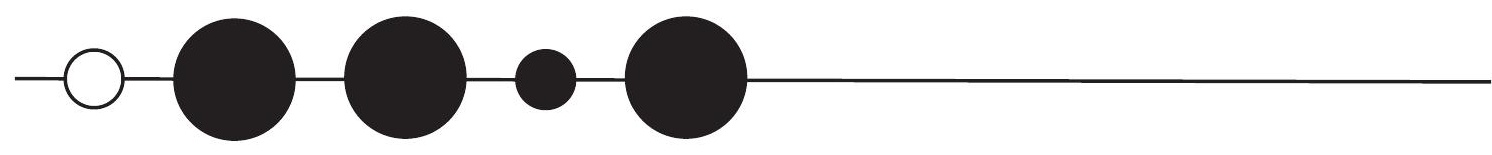




\section{INNLEDNING}

«Nils A. Butenschøn har, själv eller tillsammans med andra, öppnat vägar in i det Mellanöstern som inte bara på avstånd liknar ett kaos.» 


\title{
$\approx$ \\ ORIENTEN I SVERIGE OCH NORDEN
}

\author{
$\infty$ \\ Perspektiv på forskningens historia och möjliga framtid.
}

INGA BRANDELL \& ANNIKA RABO

Först längre fram kommer det att bli möjligt se effekterna av den arabiska våren på svensk och nordisk forskning med inriktning på länderna söder och öster om Medelhavet. Det står klart att den inspirerat avhandlingar och att fler är att vänta, och att kollektiva eller individuella forskningsprojekt med inriktning på regionen, eller som samtidigt riktar sig mot den och andra delar av världen påbörjats. Det snabba händelseförloppet från årsskiftet 2010/2011 - från Tunisien till Tahrir, och vidare - gav ett överflöd av ingångar för forskning: ungdom, sociala rörelser, revolutioner, övergång till demokrati, transitionell rättvisa, ojämlik utveckling, stad och land, sociala medier, nya massmedia, politiska partier, genus och maskulinitet. Vissa av dessa fält har nu inskränkts för empirisk forskning $i$ samhällen som drabbats av krig eller omfattande repression. Det är därför svårt att sia om hur mycket välgrundad forskning som i framtiden kan komma att läggas fram vid de svenska - och nordiska - samhällsvetenskapliga och humanistiska fakulteterna.

Frågan är också om nya temata förmår bredda kunskapen och minska upptagenheten med islam. Den som ägnat sig åt forskning eller skrivande om länderna och samhällena söder och öster om Medelhavet möts nämligen alltid, oavsett ämne, av frågan om religionens betydelse för det som avhandlas. Och med religion avses praktiskt taget alltid islam. Är detta uttryck för en allmän uppfattning att religiösa förhållanden är viktigare i just dessa områden än ekonomi, sociala strukturer, politik och ideologi? Eller vilar intresset för religionen i betraktarnas egen blick, det vill säga i det ofta dolda, men oavvisliga, förhållandet att religionen - den lutherska och den katolska - och de religiösa institutionerna åtföljde och underhöll de europeiska och nordiska samhällens övergång till moderna industri- och postindustriella välfärdsorganisationer?

Vikten av dynamiska forskningsmiljöer som inriktar sig på samhällen, kultur och politik söder och öster om Medelhavet är självklar: att precisera de historiska och geopolitiska förbindelserna mellan området och Europa är i det här sammanhanget överflödigt. De senaste decenniernas inflöde till Norden av stora invandrar- och flyktinggrupper från Turkiet, Iran, Libanon, Irak och nu senast Syrien gör dessutom att Mellanösterns samhällen nu också i någon bemärkelse finns här. Minnet av de historiska förbindelserna 


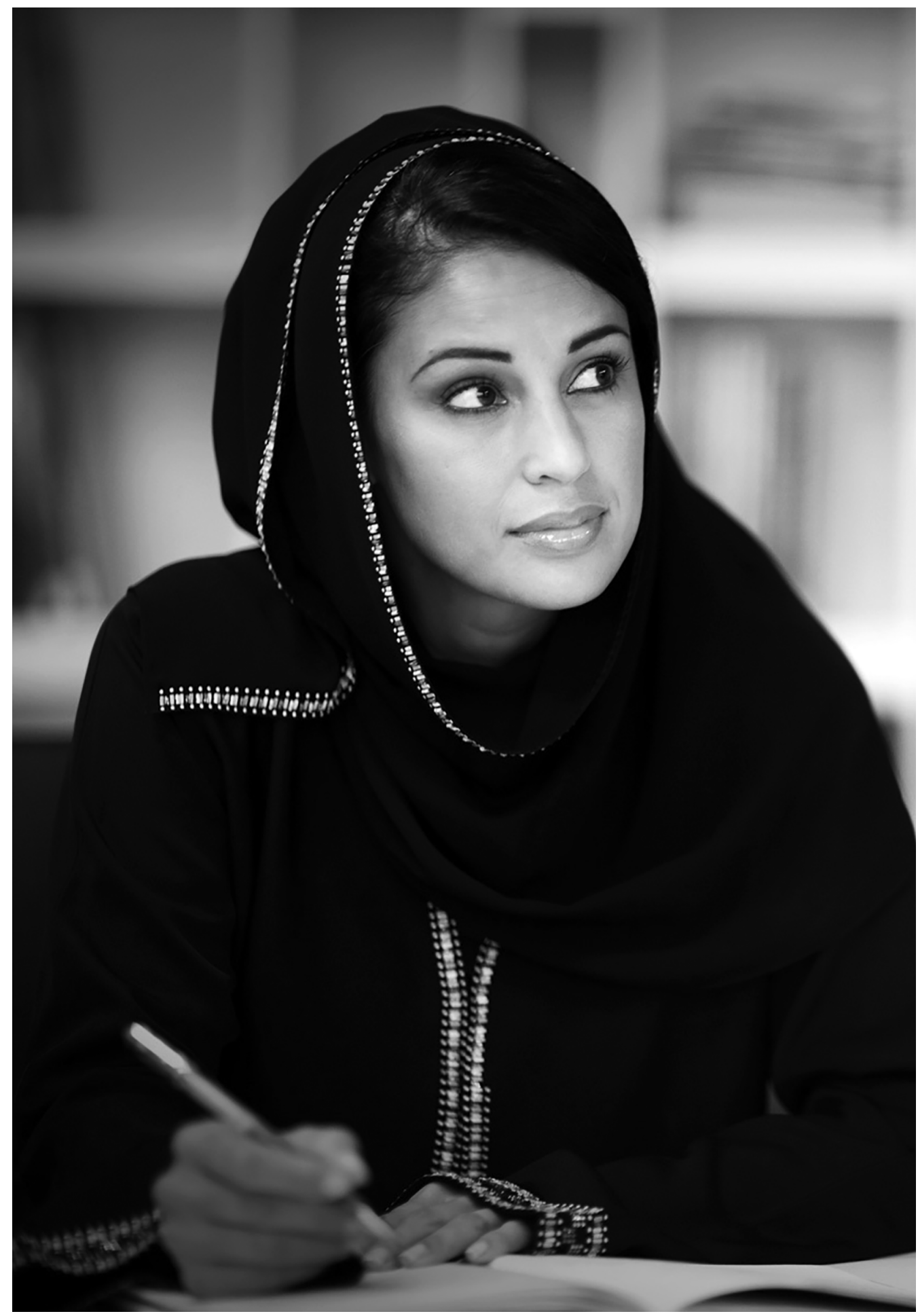


väcks, men utan tillräcklig beredskap i samtiden, varken innanför och utanför den akademiska världen. Den fördel som det på många sätt innebär att inte ha ett starkt kolonialt förflutet i regionen medför också att det saknas en samlad kunskapsbank. Även om enskilda ofta bortglömda resenärer och författare lyfts fram under de senaste decennierna, som till exempel 1600-och 1700-talets diplomater Claes Rålamb och Carl Reftelius eller mellankrigstidens journalist Karin Johnsson, ${ }^{1}$ kan de långtifrån motsvara de hyllmetrar som Napoleons expedition till Egypten 1998 och kolonialismen fyllde i andra delar av Europa.

Nils A. Butenschøn har, själv eller tillsammans med andra, öppnat vägar in i det Mellanöstern som inte bara på avstånd liknar ett kaos. Nyligen kom en bok på norska som tar utgångspunkt i en lång rad städer och ger perspektiv på samhälle och politik i stora delar av området. ${ }^{2}$ Han har också bidragit med internationella publikationer om det ämne som han odlat sedan 1990-talet, medborgarskapet, citizenship, i de arabiska länderna. Butenschøns ingång ska vi kort diskutera nedan. Men först, vad är grunden? Var står forskningen om Mellanöstern i våra länder, vilka institutionella och därmed varaktiga förutsättningar finns?

De sidor som följer diskuterar bakgrunden och ramarna för dagens samhällsvetenskapliga och humanistiska forskning med inriktning på Mellanöstern. Fokus är på Sverige, och där tillfälle ges omnämns andra nordiska länder. ${ }^{3}$ Ambitionen är att dra några slutsatser inför framtiden. Vi menar dels att språkens roll för forskningen måste klargöras, vidare att både nordiska och andra transnationella samarbeten i olika former är av vikt för att uppnå den kritiska massa som krävs, både för god forskning och för att nå utanför forskningsvärlden. Slutligen vill vi reflektera över den institutionella förankringen på universiteten, som är en förutsättning för kunskapsuppbygg- naden över tid. Frågan som ställdes ovan om den ständiga närvaron av religionen, det vill säga islam, i samtalet om Mellanöstern, kommer inte att besvaras. Men vi närmar oss den på de omvägar som utgörs av de akademiska disciplinernas framväxt och sambandet mellan det offentliga samtalet och forskningens finansieringsformer. Det tycks oss som om de finns två banor, som påverkar varandra, ibland fjärmar sig och ibland närmar sig. Den ena banan är de olika universitets-ämnenas utveckling och organisation och den plats som empiri av skilda slag från regionen kan utverka inom deras ramar. Den

\section{Modern samhällsvetenskaplig forskning om Mellanöstern kom trevande först under 1900-talets sista decennier.}

andra är det utrymme och roll som i skiftande politiska och mediala stämningslägen tilldelas Mellanösterns länder, eller om man så vill araberna (till vilka även turkar och iranier lätt kan föras), eller helt enkelt «muslimerna». Både den akademiska och den offentlig-politiska banan präglas av egna diskursiva och institutionella trögheter, men yttre händelser och, i anslutning till dem, forskningsfinansiering kan få dem att ibland korsa varandra.

\section{EN KORT OCH EN LÅNG HISTORIA}

Modern samhällsvetenskaplig forskning om Mellanöstern kom trevande först under 1900talets sista decennier. Arvet från de tidiga finländska pionjärerna, Edvard Westermarck och Hilma Granqvist, som för övrigt båda publicerade på engelska, har tagits till vara först senare. ${ }^{4}$ Internationella relationer och utvecklingsstudier kom att utgöra ramen för de första arbeten som 
publicerades, exempelvis av Daniel Heradstveit och Lars Rudebeck. ${ }^{5}$ Universalistiska teorier, om konflikter mellan stater och om politisk och socioekonomisk utveckling, skulle under de första decennierna vara styrande för de - få - avhandlingar som byggde på empiri från arabiska eller andra länder i Mellanöstern. Den första inriktningen ägnar sig huvudsakligen åt olika aspekter av de konflikter som staten Israels tillkomst givit upphov till, och hit kan föras den göteborgske statsvetaren Sune Perssons avhandling om Folke Bernadotte, FN-medlare mördad i Jerusalem 1948. ${ }^{6}$ Denna forskning hade - och har - en jordmån i de gamla intressen som funnits för «Bibelns länder och folk», konkretiserad av både svensk och nordisk närvaro $\mathrm{i}$ Jerusalem. ${ }^{7}$ I utvecklingsforskningen förekom arabiska och andra Mellanöstern-exempel, om än relativt sällsynta, mest intresse riktades mot länder och områden där nordiskt utvecklingsbistånd eller som det senare hette utvecklingssamarbete förekom, i första hand i Afrika söder om Sahara, Latinamerika och Asien.

Studier av Mellanösterns språk däremot har en lång historia, i Norden liksom i övriga Europa. Om än vindlande. Klart är att det först är under sent 1800 -tal som studiet av språken tydligt avskiljs från de teologiska studier, där hebreiska, arameiska, arabiska och så småningom övriga «orientaliska språk» haft sin hemvist sedan de första professurerna etablerades. Som exempel kan nämnas Uppsala universitet där hebreiskan för drygt fyra sekel sedan avskildes från sin tidigare plats i studiet av Gamla testamentet och gav upphov till en egen professur. En övergång följde från studiet av «bibelns språk» (hebreiska och grekiska) till studiet av de «österländska språken». Den nära förbindelsen mellan de teologiska ämnena och språkforskningen avstannade emellertid inte. Som exempel kan nämnas Tor Andræ, en annan föregångare, vars forskning under 1900-talets första hälft om profeten Muhammad och receptionen av hans lära, om sufisk mystik och islams och kristendomens ursprung, hade ett stort internationellt genomslag. ${ }^{8}$ Andræ började sina studier med litteraturhistoria och med semitiska språk för att först därefter gå över till teologi. Den motsatta rörelsens finns likaså. Ännu i sen tid har doktorsavhandlingar i teologi kunnat leda till professurer i semitiska språk i Uppsala. Forskningen om språken har naturligtvis också parallellt utvecklats i samklang med modern filologi och lingvistik, och gripit sig an litteraturhistoriska och litteraturvetenskapliga temata.

\section{OLJAN OCH ISLAM FLYTTAR IN}

Om 1960-talet var ett uppvaknande där några delar av området blev fält för forskning om internationella relationer eller om utveckling, så innebar 1970-talet att världen blev varse att den direkt påverkas av händelser i den region som kommit att bli känd som Mellanöstern: oljeembargot 1973 och det flerfaldigt ökande oljepriset var en chock, men erbjöd också affärsmöjligheter. Flera universitet i Norden tog initiativ för att förse företag med kunskap om de oljeproducerande ländernas marknader och öka affärsmännens «kulturella kompetens». Det förekom till och med diskussioner om att upprätta ett gemensamt nordiskt Arabvärldsinsitut, efter modell av Afrikainstitutet i Uppsala och Asieninstitutet i Köpenhamn. Störtandet av Reza Pahlavi Shah 1979 och den revolution som ledde till instiftandet av den islamiska republiken försvagade framförallt usA, både allmänt och i regionen. Det sovjetiska militära invasionen av Afganistan på julafton samma år fick stor inverkan på Sovjetunionen och var en faktor bakom dess fall ett drygt decennium senare.

Svallvågorna av världshändelserna nådde Norden. Jan Hjärpe, arabist och docent i religions- 
historia, publicerade detta viktiga år 1979 en populärvetenskaplig bok om islam som lära och livsmönster, och året därpå en bok om politisk islam. ${ }^{9}$ Ett par år senare, 1982, startade i Danmark ett program finansierat av Statens Humanistiska Forskningsråd med rubriken «Islam i nutiden» med delprojekt inriktade på islam och familj och samhälle/stat. Följande år blev Hjärpe innehavare av den första nordiska professuren i islamologi, vid Lunds universitet. Samma år anordnades ett symposium vid universitetet av Programmet för

\section{De inhemska muslimernas särskilda roll} gjorde det också mer legitimt att efterfråga data om dem.

Mellanöstern och Nordafrikastudier. Det utmynnade i en publikation på svenska med fler än tjugo bidrag, Religion och samhälle i Mellanöstern (1985). ${ }^{10}$ I inledningen till skriften skrev Bo Johnson Theutenberg, professor i folkrätt och vid denna tid ambassadör och folkrättslig rådgivare till Utrikesdepartementet, att 1970- och 1980talens händelser i världen tvingat fram «ett närmande mellan de politiska beslutsfattarna och vetenskapsmännen liksom mellan näringsliv och religionsvetenskapen». Theutenberg konstaterar också med tillfredsställelse att det svenska Utrikesdepartementet - «säkerligen som ett av de första i världen» - till sig knutit en «islamologexpert». ${ }^{11}$

Var det denna ansats och denna publikation som enade och lade grunden för den särskilda betydelse som religionen i Mellanöstern därefter kom att få i Sverige, både i forskningen och i offentligheten? I en rapport om islam-forskningen i Sverige till Riksbankens jubileumsfond flera decennier senare underströk Hjärpe, nu professor emeritus i islamologi, att två noder kan urskiljas inom fältet: en vid islamologin vid Centrum för teologi i Lund, där han själv handlett en hel generation forskare, och med kontakter och samarbeten vid Köpenhamns, Malmös och Växjös (Linnaeus) universitet. Den svenskspråkiga Tidskrift för Mellanösternstudier som gruppen i Lund utgav mellan 1994 och 2004 vittnar om den breda ambitionen och anspråken. Den andra noden har i Hjärpes genomgång sitt centrum vid Teologiska fakulteten i Uppsala, dit också framträdande forskare från andra discipliner rekryterats, och med samarbeten med forskare från Stockholms-universiteten.

Det är naturligtvis en god sak att det protestantiska Norden nu hyser expertis och forskning om en världsreligion som en ganska stor del av den inhemska befolkningen har en relation till. Det är dock värt att notera att katolicismen, som ju varit och är del av den europeiska politiska gemenskap som alla de nordiska länderna ingår $\mathrm{i}$ - om än Norge under egna former - knappast i samtiden varit föremål för samma akademiska intresse. Problemet är att det vid sidan av dessa miljöer för islam-forskning inte finns motsvarande livaktiga nätverk där historiska och samtida förhållanden, i regionen och i dess förbindelser med och närvaro i den övriga världen, är föremål för forskning. Särskilt kan man i Sverige notera frånvaron, eller den relativa marginaliseringen, av området inom historieforskningen.

Medeltidshistorikern och farsi-kännaren Mikael Nordberg skrev både om europeisk och asiatisk historia. Hans bok, Profetens folk, stat, samhälle och kultur $i$ islam under tusen år, först publicerad 1988, kom i flera utgåvor, men följdes inte av ny forskning och nya forskare inom historieämnet. ${ }^{12}$ Visserligen arbetar nu historikern Joachim Östlund med Sveriges och Danmarks relationer till Osmanska väldet, ${ }^{13}$ men andra historiker har övergivit Mellanöstern. I övriga 
Norden har däremot flera historiker, inriktade på äldre och modern islamisk historia varit verksamma de senaste decennierna, som till exempel Jørgen Bæk Simonsen och Jakob SkovgaardPetersen i Danmark och Knut Vikør i Norge.

\section{INSTITUTIONERNA OCH POLITIKERNA}

Är det en slump eller en effekt av enskilda framgångsrika initiativ att islamforskningen står så - relativt - stark i förhållande till andra forskningsfält? Och här korsar de två banorna varandra. I det offentliga rummet och det politiska samtalet togs under de följande årtiondena allt fler initiativ under rubriken «islam» eller «muslimerna» 1985 visar muséerna i Stockholm delar av sina samlingar under rubriken «Islam i Sverige». ${ }^{14}$ Ett decennium senare kommer ett stort anlagt svenskt utrikespolitiskt initiativ, med två internationella konferenser, 1995 och 1996 i Stockholm och i Mafraq i Jordanien. Rubriken nu är «Euro-islam», med preciseringen att de rör sig om «relationer mellan europeiska och islamiska kulturer och muslimernas ställning i Europa». Det sovjetiska imperiet hade fallit, världen var ny, Sverige trädde in i EU, i Afganistan hade talibanerna kommit till makten, och på närmare håll, i det jugoslaviska inbördeskriget, åberopades islam som en etnisk markör vid sidan av katolsk och ortodox kristendom.

Euro-islamkonferenserna följdes av ytterligare politiska initiativ. Efter attentaten i New York och Washington 2001 och invasionen av Irak 2003 tillsatte den svenska riksdagens utrikesutskott en arbetsgrupp. Dess 100-sidiga betänkande, «Vår relation till den muslimska världen i EU:s grannskapsområde», antogs av riksdagen 2006 och uttryckte krav på regeringen att «förbättra relationerna». ${ }^{15}$ Dessa olika sammankomster och texter kom att utgöra del av det svenska och det europeiska "dialoginitiativet», som kritiskt analyserats mer ingående i andra sammanhang, sär- skilt vad gäller den diskursiva - och politiska plats som den tilldelar "muslimerna i Sverige». ${ }^{16}$ Betydelsefullt i det här sammanhanget är att staterna, befolkningarna och samhällena söder och öster om Medelhavet genom dessa initiativ kom att inneslutas i den «muslimska världen». Vidare förväntades de svenska invånare, som nyligen eller för länge sedan kommit från dessa områden till Europa och Norden, ta på sig ett särskilt ansvar i utvecklingen av «relationerna mellan europeisk och islamisk kultur».

De inhemska muslimernas särskilda roll gjorde det också mer legitimt att efterfråga data om dem. Enskilda forskare tog också initiativ till att avgränsa en del av de invandrade, att räkna och studera «etniska muslimer».

Under samma period, försvagades utvecklingsstudier, som en period engagerat många discipliner, och som ibland omfattat länder söder och öster om Medelhavet, även om studieområdet fortlevde både inom undervisning och forskning. Utvecklingsbiståndet till Tunisien hade upphört under 1980-talet och därmed i stort intresset för Nordafrika. Madrid-avtalet 1991 och därefter Oslo-avtalet (1993) mellan Israel och PLO medförde ett förnyat engagemang i den israeliskpalestinska konflikten, såsom i övriga nordiska länder, inte minst Norge. Vid universitet och institut både i Bergen och Oslo har forskning bedrivits på grundval av de regelbundna undersökningar av palestiniernas levnadsförhållande som den norska Forskningsstiftelsen Fafo bedrivit eller förankrade i landets roll i förhandlingarna. Barcelona-deklarationen (1995) utmynnade i sin tur politiskt i det ovannämnda dialoginitiativet och forskningsmässigt i studier av EU-samarbetet med länder i regionen.

\section{FRÅN FRED OCH DIALOG TILL SÄKERHET}

När den svenska regeringen inom ramen för ett antal större strategiska forskningssatsningar 2008 
också intresserar sig för politiskt viktiga geografiska regioner och då väljer å ena sidan Ryssland och å andra sidan Mellanöstern, finns ekot från Madrid och Barcelona där: regeringspropositionen nämner vad gäller Mellanöstern möjligheten att «hjälpa till med fredsbevarande insatser» och att «öppna för samarbeten inom olika områden». Viktigare är dock textens inledande argument: «Politisk och religiös radikalism i Mellanöstern och Främre Asien har radikalt ändrat den globala, och svenska, säkerhetssituationen sedan den 11. september 2001. Mellanöstern framstår ur politisk synvinkel [som en] mycket viktig region» (Prop 2008/09:50). ${ }^{17}$ Medlen som regeringen ställde till förfogande ledde till skapandet av ett Centrum för Mellanösternstudier i Lund, vars mångfacetterade verksamhet lokalt och internationellt behåller ambitionen som formulerades i Theutenbergs text ovan, att «work with the business sector, state institutions and organizations». ${ }^{18}$ Här läggs en vid ram runt mycket skilda forskningsprojekt på centret och på universitetet, med en viss tonvikt på arvet från den islamologiska forskningen, vattenfrågor och migration/flyktingskap i Europa. Forskningen om den "politiska och religiösa radikalismen» överst på regeringens agenda 2008 , som i Norge till exempel direkt finansierats av Utrikesdepartementet, har i Sverige istället finansierats och drivits i första hand av andra statliga myndigheter. Myndigheten för samhällsskydd och beredskap stödjer till exempel utredningar om «islamistisk informationspåverkan» (i Sverige). Den har likaledes finansierat forskning vid Försvarshögskolans Centrum för assymetriska hot och terrorismforskning och dess senaste publikation, Mellan salafism och salafistisk jihad: Påverkan mot [sic] och utmaningar för det svenska samhället. ${ }^{19}$ Som synes har denna forskningsgren, liksom för övrigt migrationsforskningen, i allt högre grad vänt sig från det vi kallar Mellanöstern för att istället fördjupa sig i svenska förhållanden. Det kan finnas goda skäl för det. Därmed återstår emellertid frågan om hur den viktiga forskningen och spridningen av kunskap om områdena på andra sidan Europaunionens södra gräns kan främjas och förstärkas. Det gäller här att reflektera både över möjliga perspektiv och över vilka förutsättningar den akademiska världen erbjuder, institutionellt och finansiellt, för en legitim och obunden samhällsforskning bortom den «islamiska» ingången.

\section{PLATS FÖR EN OBUNDEN FORSKNING}

Problemet vad gäller forskningsansatsen är dubbelt: det gäller å ena sidan att finna tematiker som inte särskiljer dessa samhällen från andra samhällen i världen, det vill säga undvika att «islamisera» kausaliteter. Dessa tematiker kan, än så länge, huvudsakligen bara utarbetas med begreppsapparater som utformats i studiet av europeiska och nordamerikanska samhällen. $\AA$ andra sidan gäller det att finna tematiker som kan mobilisera tillräckligt många forskare för att skapa miljöer, möjliggöra finansiering och ge ett avtryck också bortom det egna empiriska fältet. För Nils A. Butenschøn har begreppet medborgarskap utgjort en sådan tematik och en ingång. ${ }^{20} \mathrm{I}$ sin senaste bok i ämnet argumenterar han, tillsammans med Roel Meijer, för att fokus på relationen medborgare-stat och medborgaremedborgare kan bidra till att förklara de dramatiska händelserna sedan 2011 och därefter, och till och med i ett längre perspektiv utgör nyckeln för att förstå den moderna arabvärldens historia. ${ }^{21}$ Butenschøn och Meijer påpekar också att begreppet har en plats inom många vetenskapsgrenar och därmed kan belysa många aspekter av samhällslivet. Vi har själva, och tillsammans med andra, på likartat sätt fokuserat teoretiska och empiriska begrepp som både möjliggör ett överbryggande av det regionsspecifika 
och som är av betydelse i flera discipliner med syfte att främja forskningsnätverk och därutöver verkliga forskningsmiljöer.

Det finns ingen anledning att här fördjupa sig i vilken utsträckning de centrala begrepp och teoretiska ansatser som valts - i Butenschøns fall medborgarskap, för oss nation och nationalism och i två kollektiva projekt stats/gränser och staters emigrationspolitik - varit välvalda. ${ }^{22}$ Att de resulterat i solid och god empirisk samhällsvetenskaplig och humanistisk forskning, där religiösa förhållanden, om de tas upp, har sin plats vid sidan av ekonomiska, sociala, politiska, rumsliga eller andra förhållanden står klart. Däremot har de inte - trots forskningsfrågornas betydelse $\mathrm{i}$ ljuset av de geopolitiska förhållandena och den förändrade befolkningssammansättningen i Norden - lett till varaktig etablering av ytterligare forskning och kunskapsproduktion om området. Denna avsaknad av institutionell kontinuitet och av kumulativitet gäller också det betydelsefulla av forskningsrådet finansierade programmet Kultur och samhälle i Väst- och Centralasien, som mellan 1996 och 2001 samlade kollektiva forskningsprojekt från flera discipliner med inriktning på området, däribland det ovannämnda projektet om statsgränser i Mellanöstern, och som påbörjade en publikationsserie hos I.B. Tauris. Vad beror dessa avbrott på?

Här ska ett försök göras att besvara den frågan, innan vi avslutningsvis lyfter några idéer om hur en breddning och förstärkning av den enligt vår mening just nu alltför islam- och terrorismdominerade forskningen skulle kunna om inte ersättas, så dock överflyglas av för humaniora och samhällsvetenskap centralare ansatser.

\section{POST-NATIONELL HISTORIEFORSKNING}

Den snabba - och med nödvändighet ytliga genomgång av hur de två banorna, den politiskmediala och den akademiska, ibland varit långt ifrån varandra och ibland korsats som här genomförts, pekar på vikten av akademins institutionella trögheter. Teologin i Sverige, från början helt uppbyggd kring Bibelns exegetik och relaterade ämnen, har när Mellanöstern tagit allt större plats i offentligheten, förmått vidga sig, och då självklart genom att inlemma islam. Vi tror att språkinstitutioner, som under århundraden frigjort sig från sina respektive värdämnen, som ofta inlemmats i större enheter under senare år, men knappast helt kommer att upphöra på de större universiteten, är det rimligaste ankaret för de nät-

\section{Vi tror att språkinstitutioner är det}

rimligaste ankaret för de nätverk och miljöer som vi hoppas på inför framtiden.

verk och miljöer som vi hoppas på inför framtiden. Det är varken självklart eller enkelt, eftersom språkinstitutionernas reella intresse för projekt som överskrider deras ämnesgränser kan vara svagt. Kanske finns här också lärdomar från övriga Norden gällande hur relevans och legitimitet i de olika disciplinerna kan bevaras för forskning och forskare verksamma utanför de egna ämnesinstitutionerna. Både i Oslo och i Köpenhamn har bredare kulturinstitutioner inlemmat språken, medan Göteborg, där arabiska huserar på Global utveckling haft svårt att skapa en «Mellanöstern-miljö». Dessutom, i en tid då forskare utan bakgrund i området rör sig in i det, i samband med studier som gäller migration, säkerhet, terrorism eller «hedersvåld», måste vikten av att forskningen går genom de relevanta språken hävdas. Det är ju på språkinstitutionerna arabiska, syriac, turkiska, farsi, de olika varianterna av kurdiska, och i framtiden kanske tamazigh, finns. 
Nästa fråga gäller hur öppenhet kan skapas inom de samhällsvetenskapliga och humanistiska ämnena för forskning med empirisk inriktning på Mellanöstern. Låt oss på nytt se på historieforskningen. Det är kanske den del av humaniora och samhällsforskning som i en bemärkelse varit starkast fångad i den så kallade «metodologiska nationalismen». Det är också den forskning som under en lång tid utgjorde en grundläggande referens för kunskapsproduktionen inom den statistiskt inriktade sociologin, den systemteoretiskt präglade statsvetenskapen, den logiskt eller pragmatiskt inriktade juridiken och den språkligt avgränsande litteraturhistorien. Men de senaste decennierna har nationsgränsernas självklarhet försvunnit. Liksom geografiämnet, som under en period, påskyndad av Sovjetunionens och bipolaritetens sammanbrott, genomlyst sina begrepp och perspektiv, har historieforskningen under tryck av «globaliseringen» låtit sig inspireras av utomdisciplinär forskning, reflekterat över de möjligheter som nya typer av observationer och data ger för analysen. Som en konsekvens stimuleras nu forskare utanför historiefacket.

Global historia, transnationell historia, «connected» eller «entangled» historia, komparativ historia, under alla dessa beteckningar kommer bidrag och förs debatter. Självklart är dessa inte oberoende varken av Braudels arbeten, eller hans sociologiska och marxistiska efterföljare som världssystemteoretikerna med Immanuel Wallerstein i täten, eller den amerikanskkanadensiske historikern William H. McNeill. McNeill kunde desto effektivare vända sig mot Francis Fukuyamas när denne 1992 lade fram sin tes om historiens slut eftersom han redan 1963 argumenterat för de oavlåtligt och ömsesidigt dynamiska effekterna av förbindelsen i historien mellan samhällen och kulturer. ${ }^{23}$ I vår samtid, och inom vårt område, kan den svenske historikern
Joachim Östlund, och islänningen Porsteinn Helgason placeras i denna nya kontext. ${ }^{24}$ Båda skriver om utbytet mellan Nordafrika, Osmanska väldet och Norden (Sverige, respektive Island/Danmark) under 1600- och 1700-tal i termer av handel, sjöröveri, militära attacker, friköpande av slavar, förhandlingar och ut-

\section{Men de senaste decennierna har nationsgränsernas självklarhet försvunnit.}

nämnande av konsuler. Forskning om samtida bistånd och biståndspolitik, EU:s eller enskilda nordiska länders, inom andra ämnen än historia skriver fram förbindelser, och deras ömsesidiga effekter. $^{25}$

En komplikation här är att de förbindelser som ligger närmast till hands i samtiden, och därmed lättast finner finansiering, är just de som i någon mening är relaterade till islam. Om Muslimska brödraskapet har spelat en viktig - av vissa uppfattad som farlig - roll i Egypten och också finns i föreningsform i Sverige är det, som exemplet ovan visade, inte svårt att argumentera för finansiering av forskning med fokus på denna organisation. Detsamma gäller den forskning med nationell eller transnationell inriktning som riktas mot Isanhängare eller -återvändare, islamistisk jihad eller islamistisk terrorism. Utan att underkänna det välgrundade och fruktbara i de enskilda projekten, finns det i det här sammanhanget anledning att påminna om Maxime Rodinson som varnade för att förklara islamiska fenomen med andra islamiska fenomen, och menade att tonvikten borde vara på de auktoritetsstrukturer, organisationsformer och styrformer som de «islamiska fenomenen» uppvisade. ${ }^{26} \mathrm{På} \mathrm{liknande} \mathrm{sätt}$ underströk islamologen Mohammed Arkoun att 
en kritisk analys av de olika «muslimska» samhällena skulle föra problemen dit där de hör, nämligen till de sociala aktörerna, och därmed också befria islam som religion från dem. ${ }^{27}$ En hållning motsatt den som hävdades av Theutenberg - och också av Hjärpe - citerad i inledningen av denna artikel.

\section{NÄTVERK, INSTITUTIONER OCH RELEVANS}

När de här sidorna skrivs, i september 2018, är sökljuset i Norden inte på Mellanöstern, inte ens på Syrien. Det danska forskningsinstitutet i Damaskus arbetar sedan 2012 från Jordanien, Libanon och Köpenhamn. Det svenska forskningsinstitutet i Istanbul har visserligen expanderat sin verksamhet, bland annat genom att ingå som en partner $\mathrm{i}$ ett större $\mathrm{EU}$ Horizon2020 projekt om syriska flyktingar, lett från Uppsala, men villkoren i dagens Turkiet är komplicerade. Den danska utrikesförvaltningen har upprättat ett «dialoginstitut» i Kairo, men beslut har fattats att stänga Svenska institutet i Alexandria som haft ett liknande uppdrag. Den europeiska organisationen för Mellanösternstudier (EURAMEs) tycks ha avsomnat, medan den nordiska motsvarigheten, sällskapet för mellanösternstudier (NSM) dock har planer både för forskarkurs och kommande konferenser. ${ }^{28}$

Dessa institutioner och nätverk har vid olika tidpunkter varit betydelsefulla för de skiftande konstellationerna inom Mellanösternforskningen. De kan också fortsättningsvis tjäna för att ta steget från nätverk till tätare miljöer. Sådana krävs nämligen för att ge kunnig omgivning för de enskilda doktorander och forskare som finns spridda på de nordiska universiteten, och för att över tid befästa forskningen och minska fragmenteringen av kunskapen i samhället. En ytterligare institution som tidigare varit av betydelse för Mellanösternforskningen är Nordiska sommaruniversitetet med dess fördel av att inte vara begränsad till området och dessutom karaktäriseras av viljan att ligga långt fram vad gäller teoretisk och metodologisk ansats. Självklart spelar en tidskrift som Babylon redan nu en roll genom att sprida forskning på de nordiska språken och ge möjligheter att föra en diskussion om förutsättningar i Norden för relevant och kumulerande forskning om dessa delar av världen.

Givet de resonemang vi ovan fört om de institutionella trögheterna i den akademiska världen förefaller det oss som om framtida initiativ för att befästa och förstärka forskningen bör utgå från de universitet i Norden där ett och helst flera av Mellanösterns språk är väl etablerade. Det är av vikt att så stor del som möjligt av den humanistiska och samhällsvetenskapliga forskningen utförs med så god kompetens som möjligt i relevanta språk - även om de «data» som används är internationella och på engelska. Det är likaledes av vikt att de som inte behärskar språken men arbetar med för området relevanta frågor vid sin sida har andra kunniga i språken att fråga till råds. Slutligen föreställer vi oss att språkinstitutionerna inte kommer att försvinna, utan tvärtom är i rimlig utsträckning skyddade i enlighet med den institutionella tröghet vi talat om. Även om forskningen på universiteten inom humaniora och samhällsvetenskap tidvis försvagas, eller övertas av mer direkt policy-inriktade institutioner, kommer det institutionella minnet av att språkämnena varit involverade i bredare forskningsprojekt att fortleva och kunna återupplivas när tiderna blir mer gynnsamma.

Samtidigt är det av stor betydelse att forskningen är av relevans för övriga involverade ämnen, historia, sociologi, religionsvetenskap och så vidare - teoretiskt och även för andra empiriska fält.. Risken är annars stor att den exotiseras, inte blir meriterande, och än en gång uppfattas behandla något islamiskt som bäst förklaras med något annat islamiskt. Frågeställningarna eller 
ansatserna bör vara tillräckligt allmängiltiga för att kunna specificeras inom den enskilda disciplinen, på det sätt som Butenschøn argumenterar för gällande medborgarskaps-begreppet och vi själva har argumenterat för nation eller gräns. Ett annat sätt kan vara att lägga sig närmare det empiriska: den tidigare professorn i iranistik i Uppsala, Bo Utas, primus motor bakom forskningsprogrammet Kultur och Samhälle i Väst- och Centralasien som nämndes ovan, föreslog vid ett tillfälle en bred forskningsansträngning om vad han kallade förmedlarna, the mediators, det vill säga de aktörer som i en eller annan kapacitet, nu eller tidigare, genom ord, varor, artefakter och andra ting, handlingar, förbundit Sverige/Norden med den sydöstra sidan av Medelhavet. En sådan ansats riskerar naturligtvis att utmynna i ett collage av studier av disparata fall. För att undvika det skulle krävas ett kontinuerligt arbete där de inblandade forskarna fördjupar den teoretiska och metodologiska ansatsen, inom sina egna ämnesramar, men också i dialog med varandra. En annan väg är att avgränsa likartade eller sammanlänkade fenomen, på båda sidor om gränsen mellan - i vårt fall Orienten och Norden, som kan studeras från olika vetenskapliga perspektiv. Det är vad historiken Samuel England gör i sin bok Medieval Empires and the Culture of Competition, men kan naturligtvis också tillämpas på - väl valda - senare eller samtida fenomen. ${ }^{29}$

\section{EN KOMMANDE DISKUSSION}

Sammanfattningsvis hoppas vi att en nordisk diskussion kan utvecklas, vid sällskapets konferens 2019 i Helsingfors eller i Babylons spalter eller annorstädes, om framtiden för vårt forskningsområde. Självklart utesluter inte en sådan de europeiska och internationella kontakterna, desto mer så när den internationaliserade rekryteringen leder till allt fler utomnordiska anställda på våra universitet och institut. Den nordiska ramen behåller dock samtidigt sin relevans för den samhälleliga kontexten. En sådan diskussion kan på sikt leda till teoretisk och empirisk fördjupning av den «connectedness», det vill säga sammanlänkning i historien och i samtiden, som vi argumenterat för ovan. Den behöver innehålla ett utbyte av erfarenheter och kanske gemensamma framtida ansträngningar på tre områden: för det första gäller det hur institutionell akademisk förankring över tid kan befästas, för det andra hur forskarsamhället kan ta på sig sitt ansvar för att de relevanta språkkunskaperna bibringas nya generationer, och slutligen hur vi skapar utrymme för att reflektera över och påverka en annan «connectedness» som vi också lyft fram ovan, nämligen den mellan de två banorna, de politiska och mediala stämningslägena och produktionen av vetenskaplig kunskap.

\section{- $f$ •}

INGA BRANDELL är professor emeritus i statsvetenskap vid Södertörns Högskola, ANNIKA RABO är professor emeritus i socialantropologi vid Stockholms universitet.

1 Karin Ådahl, red. The Sultan's Procession. The Swedish Embassy to Sultan mehmed IV in 1657-1658 and the Rålamb Paintings (Istanbul: Swedish Research Institute in Istanbul, 2006); Joachim Östlund, Saltets pris: svenska slavar $i$ Nordafrika och handeln i Medelhavet 1650-1770 (Lund: Nordic Academic Press, 2014); Tetz Rooke, «Travel and translation, the case of Karin Johnson», i Borders and the Changing Boundaries of Knowledge, red. Inga Brandell, Marie Carlson och Önver Cetrez (Istanbul: Transactions 22, Swedish Research Institute in Istanbul, 2015), 129-144.

2 Nils A. Butenschøn och Rania Maktabi, Brennpunkt Midtøsten: Byene som prisme (Oslo: Universitetsforlaget, 2018).

3 För ett bidrag om utvecklingen av mellanöstern stider i Finland se Jaakko Hämeen-Anttila, «Middle Eastern Studies in Finland», Middle East Studies Association Bulletin 38, nr.1 (2004): 41-43.

4 Edvard Westermarck, Marriage Ceremonies in Morocco (London: Macmillan, 1914); Edvard Westermarck, Ritual and Belief in Morocco (London: Macmillan, 1926); Hilma Granqvist, Marriage Conditions in a Palestinian Village (Helsingfors: Societas Scientiarium Fennica, 1931).

5 Daniel Heradstveit, Brennpunkt Midt-Austen: ein analyse av situasjonen etter juni-krigen 1967 (Oslo: Universitetsforlaget, 
1971); Lars Rudebeck, Party and People. A Study of Political Change in Tunisia (Stockholm: Almqvist \& Wiksell, 1967).

6 Sune Persson, Mediation \& Assassination (London: Ithaca press, 1979).

7 Se till exempel Hans Morten Haugen, «Kirkene og Israel», Babylon 4, nr. 2 (2006): 22-31.

8 Tor Andræ, Muhammad: hans liv och hans tro (Stockholm: Natur och kultur, 1930); Tor Andræ, I myrtenträdgården: studier i sufisk mystik (Stockholm: Bonniers, 1947).

9 Jan Hjärpe, Islam. Lära och livsmönster (Stockholm: AWE Gebers, 1979); Jan Hjärpe, Politisk islam (Stockholm: Skead, 1980).

10 Jan Hjärpe och Jan-Olaf Blichfeldt, red. Religion och samhälle $i$ Mellanöstern (Löberöd: Plus ultra, 1985).

11 Bo Johnson Teutenberg, «Religionen i världspolitiken», i Religion och samhälle i Mellanöstern, red. Jan Hjärpe och JanOlaf Blichfeldt (Löberöd: Plus ultra, 1985), 9 och 12.

12 Mikael Nordberg, Profetens folk: stat, samhälle och kultur $i$ islam under tusen år (Stockholm: Tiden, 1988).

13 Joachim Östlund, Saltets pris: svenska slavar i Nordafrika och handeln i Medelhavet 1650-1770 (Lund: Nordic Academic Press, 2014).

14 Ulla Wagner, Suzanne Unge och Annika Richert, Islam, religion, kultur, samhälle (Stockholm: Gidlunds \& Statens historiska museum, 1985.)

15 Sveriges Riksdag. Vår relation till den muslimska världen i EU:s grannskapsområde, Utrikesutskottets betänkande 2005/06:UU8.

16 Inga Brandell, «Aguéli i Egypten: entente cordiale mellan Occidenten och Orienten", i Humanister forskar, red. Gunilla Ransbo (Uppsala: Uppsala universitet, 2006), 11-20; Annika Rabo, «Once you were great' Orientalism reconsidered: the case of Sweden», Orientalism Reconsidered. Emerging Perspectives in Contemporary Arab and Islamic Studies. Paper presented at University of Exeter, April 18-19, 2001 at a conference in honour of Edward Said and Mohammed Arkoun; Annika Rabo, «När Mellanöstern blev den 'muslimska världen'», Babylon 4 nr.2 (2006), 32-41.

17 Sveriges Regering. Ett lyft för forskning och innovation. Proposition 2008/09:50.

18 «About Us», Center for Middle Eastern Studies, sist endret 12. oktober 2018, cmes.lu.se/about-cmes/

19 Magnus Ranstorp, Filip Ahlin, Peder Hyllengren och Magnus Normark, Mellan salafism och salafistisk jihad: Påverkan mot och utmaningar för det svenska samhället (Stockholm: Försvarshögskolan, 2018).

20 Se till exempel Nils A. Butenschøn, Uri Davis och Manuel S. Hassassian, Citizenship and the State in the Middle-East. Approaches and Applications (Syracuse: Syracuse University Press, 2000).
21 Nils A. Butenschøn och Roel Meijer, red. The Crisis of Citizenship in the Arab World (Leiden: Brill, 2017).

22 Inga Brandell och Annika Rabo, «Arab nations and nationalism: dangers and virtues of transgressing disciplines», Orientalia Suecana LI-LII (2002-2003): 35-46; Inga Brandell, red. State frontiers, Borders and Boundaries in the Middle East (London, New York: I.B.Tauris, 2006).

23 William H. McNeill, The Rise of the West. A History of the Human Community (Chicago: University of Chicago Press, 1963).

24 Porsteinn Helgason, The Corsair's Longest Voyage. The Turkish Raid in Iceland 1627 (Leiden: Brill, 2018); Joachim Östlund, Saltets pris: svenska slavar $i$ Nordafrika och handeln $i$ Medelhavet 1650-1770 (Lund: Nordic Academic Press, 2014).

25 Se till exempel Niklas Bremberg, Exploring the Dynamics of Security Community-building in the Post-Cold War Era: Spain, Morocco and the European Union (Stockholm: Stockholm Studies in Politics, Stockholm University, 2012); Ann-Kristin Jonasson, The EU's Democracy Promotion and the Mediterranean Neighbours. Orientation, Ownership and Dialogue in Jordan and Turkey (London: Routledge, 2013).

26 Maxime Rodinson, L'Islam: politique et croyance (Paris: Fayard, 1993).

27 Mohammed Arkoun, Ouvertures sur l'Islam (Paris: J.Grancher, 1989).

28 Se «Welcome to NSM!», Nordic Society for Middle Eastern Studies, thenordicsociety.se/.

29 Samuel England, Medieval Empires and the Culture of Competition. Literary Duels at Islamic and Christian Courts (Edinburgh: Edinburgh University Press, 2017). 